\title{
Leadership: the ghost at the trillion dollar crash?
}

\author{
Douglas Board* \\ University of Hertfordshire, Complexity and Management Centre, \\ Hatfield AL10 9AB, UK
}

\section{Keywords}

Leadership; governance; financial crisis; systems thinking; management as science.

\begin{abstract}
Leadership has been largely overlooked by bankers, regulators, policy-makers and scholars trying to discern the cause of the global financial crisis. The paper suggests that this is odd, given the attention (both theoretical and practical) commanded by the subject over the past 30 years. Drawing on the author's experience in executive search and analysing critically the lessons proposed by the UK's inquiry into bank governance, this paper argues that common ways of leading and of thinking about leadership, in conjunction with systems thinking, helped cause this crisis and are already contributing to the next. While some scholars have offered important and relevant critiques, the dominant discourse on leadership remains dangerously unperturbed.
\end{abstract}

*Tel: +44 (0)7957 140 776. Fax: +44 (0)20 7252 2915. E-mail address: douglas@maslowsattic.com 


\section{Leadership: the ghost at the trillion dollar crash?}

\section{Introduction}

What lessons are we learning from the global financial crisis? James Dean, Dean of Kenan-Flagler business school, is in no doubt: 'If the financial crisis has taught us nothing else, it is that people in the financial industry need leadership. ${ }^{1}$

Jessica Einhorn, Dean of the School for Advanced International Studies at Johns Hopkins, proposes a parallel priority: 'If there is one thing we should have learnt in the past year, it is that we need to hold our public officials accountable for thinking through systemic issues. 2

This paper questions the present day combination of leadership with systems thinking. After noting the scale of the present crash, the dramatic growth in attention given by managers and scholars alike to leadership during the past 30 years is recalled. If there has been a leadership boom why is that boom so little discussed in post mortems of the financial bust by bankers, regulators, policy-makers and scholars ${ }^{3}$ ? This paper argues that despite the shift towards more complex, less mechanistic thinking in economics, the dominant lesson-learning from this global trauma remains inadequate.

As a leading financial centre the UK was particularly involved in the global crisis. This paper will look at the work commissioned by the UK Prime Minister from Sir David Walker to identify lessons for the boardrooms of banks themselves (Walker 2009a, 2009b). Walker was appointed in February 2009 to examine corporate governance in the UK banking industry in the light of the financial crisis. A former deputy chairman of Lloyds Bank and chairman of Morgan Stanley International, Walker also worked at the Bank of England and chaired the UK's securities regulator. Rather than debate the merits of Walker's proposals (which in any case sit within one country's governance context) this paper seeks to exploit the clarity of his views, rooted in wide senior experience and supported by extensive consultation, to illuminate the broader assumptions about leadership upon which his recommendations rely.

\section{The trillion dollar crash}

Highly paid bank executives turn out to have driven their complex juggernauts very fast into ice and fog. If the risks they faced were so complex and unclear, what on earth were they doing driving at that speed and in such close formation?

\footnotetext{
${ }^{1}$ Financial Times, London, 6 July 2009.

${ }^{2}$ Financial Times, London, 20 March 2009.

${ }^{3}$ Such as those by Gieve, Greenspan, Turner and Wolf cited below. 
To speak of a trillion dollar crash is quite conservative. In October 2009 the International Monetary Fund estimated the total worldwide losses from bad loans and securities at \$3.4 trillion, of which they reckoned that banks so far had woken up to slightly less than half (IMF, 2009).

In May 2009 the European Central Bank put the writedowns of euro area banks reported to that point at $18 \%$ of the global total. The loss to that date of economic output in the euro area was estimated at $€ 400$ billion (5\% of GDP), and the potential commitment of governmental support (capital and guarantees) to euro area banks at $€ 413$ billion (Papademos, 2009).

The UK was worse hit. Walker estimated the total support provided to the banks by the UK taxpayer at $£ 1.3$ trillion, or some 90 per cent of GDP (2009a, p. 90) - in other words the magnitude of everyone in the UK working free for the banks for nearly eleven months.

In terms of cost rather than exposure, in December 2009 the UK government reduced its estimate of the bill from bank bail-outs from $£ 20-50$ billion to $£ 10$ billion (H M Treasury, 2009, p. 199). $£ 10$ billion used to be a large sum but (thanks to the crisis) it is now loose change! The taxpayer could even make a profit. But this is only cost narrowly interpreted. If some kids 'borrow' a Lamborghini for a weekend, the cost to the owner might turn out to be only a tankful of petrol, or even a profit if one of the joyriders drops his wallet. But that hardly measures the risk or the outrage ${ }^{4}$.

The wreckage is vast. So what were the drivers - the boards of these banks, not least their top executive leaders - doing? By a large majority these were highly intelligent and relevantly experienced individuals. Did they not see dangers developing? Or were they lining their own pockets at the expense of their shareholders because, as economists put it, their interests were misaligned? Both of these explanations fail to grasp the nature of what has happened.

Banks' leaderships were, by their own lights, active and alert. For example, in evidence to the UK Parliament, Andy Hornby, chief executive of the (then) major retail bank HBOS, described conserving capital and reducing the bank's market share of net mortgage lending to $8 \%$ by 2008 from $25 \%$. Moreover:

... we recognised the fact that the wholesale markets [from which HBOS drew much of its funding] were getting an awful lot more difficult. We had already considerably extended the longevity of our wholesale funding. (UK Parliament, 2009a, Q862)

\footnotetext{
${ }^{4}$ On a cost basis but including the impact of the crisis on economic growth, one estimate is of a cumulative loss to the UK economy of $160 \%$ of GDP (£2.2 trillion). The impact of the financial crisis interventions on UK public sector net debt is estimated at about $£ 1.5$ trillion (Kellaway, 2009, p. 137).
} 
Foolish judgements were still made, such as the $£ 40$ billion of HBOS' corporate loan book accounted for by construction and property companies, but not thanks to the board being asleep on the job. HBOS chair Lord Stevenson affirmed:

Clearly, given the deterioration in markets and the deterioration in asset values, we lent too much and [the corporate] division lent too much. That the board was hugely engaged in it, I can assure you. (Ibid., Q953)

Or, in the case of the Royal Bank of Scotland's acquisition of parts of ABN Amro for $£ 10$ billion, which then-chairman Sir Tom McKillop later acknowledged as 'a bad mistake' (ibid., Q795), McKillop said:

The [RBS] board had 18 meetings ... ABN Amro was considered at every one of those. ... At every stage the whole board considered this and was unanimous in the steps we took. (ibid., Q789)

So at an institutional level we are talking about very active leadership up to and into the crisis. The lights in the boardroom were on.

The interests of key players were also in large measure aligned with those of shareholders. Lord Turner, chairman of the Financial Services Authority (FSA), the regulator of banking and financial services in the UK, pointed out that 'the head of Lehman Brothers owned a hell of a lot of the stock of Lehman's' (UK Parliament, 2009b, Q2233); while in Hornby's case:

... last year, in common with every single year for the previous eight years, I invested my entire cash bonus in shares.... My interests have been entirely aligned with shareholders and I never received one single penny of cash bonuses. $\ldots$ in the two years that I have been chief executive I have lost considerably more money in my shares than I have been paid. (UK Parliament, 2009a, Q 7756)

What flows from acceptance of these core propositions in the post mortem literature is that the firms' leaders were good, skilled people, trying hard to make their shareholders richer. If anything can avert future crises of this magnitude, so this analysis goes, it is not better or different executive leadership. We have to look outside the firms at the market or the system as a whole.

The Financial Times had no doubts on this score. The drivers of financial juggernauts hurtling into ice and fog were not fundamentally to blame. Rather this, from an editorial in May 2009:

As a shell-shocked world tries to fathom how its economic collapse happened, commentators are busily outbidding each other with claims about the exceptional nature of this crisis. But the most astounding fact is how familiar its physiognomy and physiology look compared to past financial crashes. 
No-one can read the chronicles of those earlier crashes without sensing - with a chill - that history is repeating itself.

... This was not a failure of markets; it was a failure to create proper markets. What is to blame is a certain mindset, embodied not least by Mr Greenspan. It ignored a capitalist economy's inherent instabilities - and therefore relieved policymakers who could manage those instabilities of their responsibility to do so. This is not the bankruptcy of a social system, but the intellectual and moral failure of those who were in charge of it: a failure for which there is no excuse. (Financial Times, 2009, p. 39)

Well, that's it, then. Or is it? If we're thinking about booms and busts, what about the boom in leadership during the past 30 years? Does that boom have anything to do with this bust?

\section{Leadership: boom and corruption}

In the 1970s, writing about leadership was in the doldrums. But in America Burns wrote 'Leadership' (1978), which linked political and organisational leadership and suggested that leadership could be transformational; and in 1979 the UK acquired a Prime Minister (Margaret Thatcher) subsequently regarded as transformational. Since then there has been an explosion of recommended ways of being a leader, including situational leadership, leaders as creators or guardians of values or innovation, or organisational learning, or fun: in each case positing that excellent leadership is a critical ingredient for organisational success.

Although hero-stories proliferated, whether of the autocratic or empowering kinds such as Jack Welch of General Electric, reputed like the neutron bomb to eliminate employees while leaving buildings standing, or the Brazilian Ricardo Semler of Semco, whose managers set their own salaries - we also encountered Collins' humble 'level 5 leaders' (Collins, 2001) as well as suggestions, for example from Kotter, that everyone should be a leader (Kotter, 1988). Approaching the new millennium chaos and complexity gained strength as themes: for example Wheatley (1999) and Vaill (1989).

The leadership boom did not only spawn books. Organisations spent millions to buy and to make exceptional leaders: fees to search firms to find these individuals, and fees to business schools to run courses to make them. Now if leadership is so critical to organisational success, how can it hardly figure in a discussion of massive, multiple organisational failure? Why are remuneration and incentive structures the only aspects of leadership currently subject to intense scrutiny? Why is Mintzberg in a minority when he insists: 'This is not a financial crisis, it is a management crisis' (Mintzberg, 2009)? 
This ghostly vanishing act is even odder since many consider leadership to play a critical role in deep learning (Senge, 1990)(Argyris, 1990)(Nonaka and Takeuchi, 1995). Is leadership itself now exposed as a bubble, like sub-prime mortgages?

Some questioning strands have emerged within business schools within the last five years. Sumantra Ghoshal condemned the trend he perceived which increasingly drained management of its ethical dilemmas and turned it into a pseudo-science (Ghoshal, 2005). Rakesh Khurana analysed that trend in detail: he showed how during the first century of their existence American business schools had taken the path which had alarmed Ghoshal (Khurana, 2007). Business schools were the place where the concept of management as a complex, ethically significant activity began a long retreat during the twentieth century, yielding ultimately to the maximisation of an apparently objective quantity - shareholder value. By contrast in 2009 more than half of Harvard's graduating MBA class created and signed an oath affirming that management is an ethical activity to be conducted with regard not only to the interests of shareholders but society at large.

On this side of the Atlantic researchers at Manchester performed a remarkable financial and narrative deconstruction. They took what the leaders of three iconic firms (GlaxoSmithKline, Ford and General Electric) had said about value creation over 20 years and, by contrast, what their firms had done (Froud et al., 2006). They assembled a picture of what one might call the corruption of leadership, even in the most rigorous and blue-chip of business environments. Leadership became whatever would plausibly promise the results which investors were believed to want to hear. In their words:

We argue that the changes around strategy are part of a broader process that we understand as financialization, the term we use to denote the changes induced by the rhetoric of shareholder value. In our view, the process of financialization sets firms and households utopian objectives such as value creation by management intervention for giant firms or security through stock-market saving for households. On the evidence we cite, this corporate objective is almost certainly unrealizable in most firms most of the time, yet the world may be changed by management's attempt to achieve that objective. (Froud et al., 2006, p. 4)

At this point a connection should be made with the author's practice as an executive search professional. The spread of targetry, as well as the emulation of many other things private, rapidly penetrated the UK public sector (Barber, 2008). Whether in the private or the public sectors, desired leaders were individuals who plausibly promised transformational or 'step' changes so organisations could break with decline or incrementalism. The author played a part in enacting a leadership algebra, in which leadership becomes 'whatever it takes' to move an organisation from its present state (A) to some exogenously specified future state (B) in 3 years (or in difficult cases, 5):

$$
\mathrm{X}=(\mathrm{B}-\mathrm{A}) / 3 \text {. }
$$


To act in this way makes choosing leaders something like bid-and-deliver, as with rail or other privatised franchises: who promises, (for the moment) wins. Who wins, appoints others who 'bring solutions, not problems'. And whoever wins, both preaches a transformational rhetoric and inhales it, because we also demand that we can touch our leaders and judge them sincere. We want to believe that our leaders believe. Over-reaching ambition, a vital ingredient of boom-and-bust, seems built into this leadership model.

Bid-and-deliver leadership takes anything as possible: the equation is hospitable to setting ' $\mathrm{B}$ ' as whatever you like. In fact it contains the seeds of totalitarianism. The political scientist Hannah Arendt studied totalitarianism not as the behaviour of extraordinarily evil people but as a phenomenon which only became possible in modernity. For her, its characteristic features were an ideology of apparently compelling necessity, the belief that 'everything is possible', and becoming mesmerised by change, not experienced reality: an 'emancipation of thought from experience' (Canovan, 1992, pp. 75, 90). For Arendt totalitarianism is not possible while people remain simply greedy (Arendt, 2003a, 2003b): it needs a transforming vision and a hubristic science. Modern management demands one and claims to be the other.

But now consider what happens outside firms, in the arena of policy, regulation and systems thinking where most of the post mortem debate is focussed.

\section{Regulation and systems thinking}

To modern minds the principle of systems thinking is disarmingly obvious: a system is something which cannot be understood at the level of parts, but must be grasped as an interacting whole. Thus:

Simply defined, a system is a complex whole the functioning of which depends on its parts and the interactions between those parts. Stated like this, it is clear that we can identify systems of very different types:

- physical, such as river systems;

- biological, such as living organisms;

- designed, such as automobiles;

- abstract, such as philosophical systems;

- social, such as families;

- human activity, such as systems to ensure the quality of products.

(Jackson, 2003, p. 3)

We think in this way when we talk about seeing 'the big picture'. Seeing the big picture is what one needs to do with systems. Recall the view of the Financial Times: the lorry drivers were not driving too fast, it was the failure of those 'in charge' of the 
system which was inexcusable. On this view it was the job of policy-makers and regulators to see the bigger picture - the market or the economy - and to stop the system going astray.

Without doubt, the crisis has raised a host of urgent and difficult systemic questions, such as how do we get out of the 'too big to fail' trap. Consider two examples.

Then Deputy Governor of the Bank of England Sir John Gieve pointed out one large flaw in the individual firm perspective:

... the ideal risk management system for a single bank is one which lets it dance until the music stops but then gets to the exits before its competitors ... the investment banks which did best in 2007 were not those which had stepped back from the new markets well in advance but those which reacted most quickly and cohesively when the trouble started in the summer of 07 .

Of course banks need to ... improve their own information and control systems. But in a competition someone always has to come last and what matters for the authorities is how much the weakest will be damaged and how far that damage will spread through the system. (Gieve, 2009, p. 6)

Some important systemic judgements proved mistaken: credit securitisation, for example, which re-packages loans into goods which institutions can buy and sell. As formulated by the International Monetary Fund, the systemic perspective of practitioners, academics and policy-makers in 2006 was benign:

... the dispersion of credit risk by banks to a broader and more diverse set of investors, rather than warehousing such risk on their balance sheets, [made] the banking and overall financial system more resilient. (FSA, 2009, p. 42)

But in reality, concluded the chairman of the UK's regulator:

... the majority of the holdings of the securitised credit, and the vast majority of the losses which arose, did not lie in the books of end investors intending to hold the assets to maturity, but on the books of highly leveraged banks and bank-like institutions. (Turner, 2009, p. 4)

Or, as the economist Martin Wolf proposes:

The proposition that sophisticated finance was able to transfer risk to those best able to manage it has failed. The paradigm is, instead, that risk has been transferred to those least able to understand it. (Wolf, 2009, p. 8)

Systemic questions are very important. It is hardly surprising that the first section of the Financial Services Authority's conclusions on 'What to do?' is entitled 'The need for a systemic approach' (FSA, 2009, p. 52). But systemic thinking is only one family 
of ways of attempting to think more adequately about large and complex interaction the big picture way - and it has consequences which we often forget.

Firstly, we tend to picture that we are talking about an objective reality, like a physical object. This is akin to the pseudo-scientific perspective about which Ghoshal (and others) sounded the alarm. We think of the big picture, not the big pictures.

'The systems view' makes special the single, coherent view of a supposed detached observer'. It becomes a 'best view' which every participant should want to make the foundation of their own decision-making. So, if this view can be constructed, and especially if it becomes (as, on the face of things, it should) the bedrock for systemwide regulatory policies, it has a homogenising effect, weakening the diversity of thought and action and the liquidity of markets, in which our collective capacity to respond to shocks might lie 6 . Thus Mainelli has pointed out that smart systems models, greater disclosure and mark-to-market accounting (each of which can be viewed in isolation as 'motherhood and apple pie'), have increased market homogenisation and damaged liquidity and resilience (Mainelli and Giffords, 2009, pp. 44-50, 56).

Secondly, what the big picture misses out is the one who sees and paints it $-u s$. The picture understates the complexity of what it portrays. We have to paint ourselves back in. In the case of financial markets, Soros has particularly grappled with this (Soros, 2008). As self-aware, reflexive beings, in the very act of understanding systems of which we are a part, we change unpredictably what we understand. Of course, in many parts of management studies this is a familiar point: but it is not selfevident in finance or economics.

And if the one who sees and presents a big picture is a powerful leader, then their disappearance from the picture matters even more. In the practice of recruitment, leadership and systems thinking fuse into the ubiquitous client demand for 'leaders with strategic vision', 'who see the big picture'. Like the giant plasma television screen in the January sale it sounds irresistible - who wants a leader who sees less? But what is obscured is that watching television is not the only way of seeing in the world.

Remembering Arendt, the combination of a compelling vision (produced by leaders) with a hubristic science (systems thinking) may alert us to the potentiality for creeping totalitarianism. As analysed by Douglas Griffin, precisely this combination tends towards the ethically denuded world described by Ghoshal and Khurana. The deformation of human moral stature arises (in the case of those who are led) by

\footnotetext{
${ }^{5}$ There are attempts to create 'postmodern systems thinking' but quite often these revert to modernism with added emphasis on plurality of information and communication: we need 'more reason - to overcome the difficulties on which the postmodernists focus - rather than less.' (Jackson, 2003, pp. 255-274)

${ }^{6} \mathrm{Cf}$ monocropping in agriculture. However in making biological analogies, it is worth distinguishing variety from inter-connectedness: Robert May has pointed out that the idea of richly inter-connected ecosystems as the most stable is incorrect (Financial Times, 27 November 2009).
} 
expecting of them little more than the execution of predetermined purposes, like rats salivating over cheese, or (in the case of leaders) treating them as chimeras, on some days rats chasing cheese but on special days capable of sophisticated moral thought (Griffin, 2002, pp. 48-54).

Crucially we are also describing a world which desires conflict and challenge to disappear or to be managed by an elite in special, hygienic conditions (ibid., pp. 1967). Let us see how this happens as we study the Walker reports, whose central judgement is the 'seriously inadequate' degree of challenge in banks' boardrooms to the proposals of powerful executives (Walker, 2009b, pp. 52, 52-67).

\section{Large-firm leadership in practice}

'How banks are run,' Walker says, 'is a matter for their boards' (ibid., p. 6). Recall we are not judging his recommendations but using them as a tool of inquiry. Rooted in deep experience of corporate leadership and regulation, and informed by wide consultation, what picture of contemporary large-firm leadership emerges from his work?

This is Walker's starting point:

the most important factor in ensuring long-term corporate success ... is a highly effective executive team that is not dominated by a single voice; where open challenge and debate occurs; and yet the executive team is cohesive and collectively strong. (ibid., p. 35)

He then acknowledges some risks, for example that:

... the style and entrenchment of the CEO blocks the possibility of constructive challenge from within the executive team ... the greater the entrenchment of the CEO, perhaps partly on the basis of excellent past performance and longevity in the role, the greater is likely to be the risk of CEO hubris or arrogance ... (ibid., pp. 42, 53)

Moreover this risk is not idiosyncratic but connected to a prevalent leadership model:

... [the CEO] is unlikely to be in the role without having displayed qualities of competence and toughness which are not dependably tolerant of challenge.

(Ibid., p. 53)

Now these executives need rigorous challenge by the non-executives, yet a certain deference is present in Walker himself when he defines the kind of boardroom challenge which he thinks it is good for the executives of a company to face. This is challenge which: 
... leaves the executive team with a sense of having drawn benefit from it. (Ibid., p. 54)

Which is interesting: in a marriage could we say, only argue with your partner when with hindsight your partner will be pleased that you did?

Moreover this is a challenge of unequals. Executives command a vastly greater information and analytical base than non-executives. Since the consequences of inadequate challenge have run into trillions of dollars, one might imagine that nonexecutives would need high quality, independent information. But Walker becomes intensely wary here, and what he is wary of is creating conflict:

Some suggestion has been made that NEDs [non-executive directors] should not only (as now) have access to but should be expected to make regular use of advice from sources outside the company. But such external involvement would be unlikely to provide more dependable support than that provided by the company secretariat (or some other dedicated internal capability) and could risk generating needless friction with the executive. (Ibid., p. 47)

So he rules this out, with the important exception of the governance of risk - in financial institutions managing risk is particularly critical. But he dilutes what he first proposed. He still proposes a dedicated board risk committee and a chief risk officer protected by the board against removal or interference in her pay by the CEO (ibid., pp. 94, 98). But whereas in July 2009 he proposed that the committee should

'in the normal course expect to draw on external input to its work' (Walker, 2009a, p. 87)

and report publicly whether it had done so (ibid., p. 89), in November he noted that the relations between board and staff, particularly the new chief risk officer,

'could be undermined if internal advice is regularly subjected to second-guessing from outside' (Walker, 2009b, p. 101).

Thus his final conclusion is simply that the board risk committee 'should be attentive to the potential added value from seeking external input' (ibid., p. 102).

So, for fear of generating 'needless friction' with their own senior, highly paid and (by admission) strong-willed staff, apparently it is too much to say that those responsible for the driving of lorries should normally cross-check internal information with external.

This suggests something quite brittle about the everyday leadership of large firms, far distant from the plurality-with-cohesion with which Walker started. The boardroom starts to emerge as a special, hygienic place for conflict and challenge conducted by the highly skilled. 
What follows is the need (ibid., pp. 56-57) for boardroom chairs who are unusually adept at steering and managing conflict. Walker thought these issues sufficiently important that he added to his final report an appendix on 'Psychological and behavioural elements in board performance'. It speaks inter alia about the need for board members to have 'highly-tuned facilitation and listening skills' (ibid., p. 142). But at the same time Walker acknowledges that bank boards need to become smaller (ibid., p. 41) and be drawn even more closely from the pool of proven senior executives, especially those with experience in financial services (ibid., pp. 43-44). So the increased challenge needed to avert the next crisis has to be created within boardrooms even more dominated than today by executives 'not dependably tolerant' of challenge, and so unpractised at it.

This transformation of skills when executives are swept up into the boardroom is accompanied by a surprising change of motivation. Having devoted 20 pages of his report to re-structuring bank executives' financial incentives, with requirements for disclosure and precise limits on the extent to which incentives can kick in after 1, 3 and 5 years (ibid., pp. 106-126) - a re-positioning of pieces of cheese at various distances in front of rats - Walker re-affirms that chairs should be paid a flat fee (ibid., p. 121). Chairs should be far-seeing and wise, not bonus-driven. In July he had commented:

For a chairman who proves not to be up to [the long-term focus of] this role, the best course is likely to be for shareholders and the board to press for change rather than to seek to fine-tune the chairman's remuneration. (Walker, 2009a, p. 101)

But of course chairmen should 'preferably' have had 'an earlier senior executive role in banking' (Walker, 2009b, p. 58). Thus the long-term sage and the cheese-seeking rat turn out to be the same person. On this reasoning the elevation of executives to non-executive roles becomes faintly reminiscent of bodily assumption into heaven.

\section{Are there better lessons to learn?}

In terms of the need for lesson-learning combined with the scale of human resources actually mobilised in that pursuit, the trillion dollar crash should rank as one of humanity's most significant learning opportunities: but are we doing well enough? Probably not.

Two sources already quoted have relied on non sequiturs of significant proportions. Walker argues:

... the fact that different banks operating in the same geography, in the same financial and market environment and under the same regulatory arrangements 
generated such massively different outcomes can only be fully explained in terms of differences in the way they were run (Walker, 2009b, p. 6)

which neglects random variation and the sensitivity of complex figurations to small differences.

Or recall the Financial Times lambasting policy-makers for having failed to learn from centuries of booms and busts, which take a chillingly similar shape. But is this not like lambasting a goal-keeper for 'failing to learn' from the chillingly similar shapes of the ballooning net on the occasions when she fails to stop the ball shooting past? More relevant might be whether she has made any saves ${ }^{7}$.

Is 2010's thinking going to be any better than 2009's? To judge by two contrasting books which have come out at the start of the year, there are glimmers of hope, but we shouldn't hold our breath. Stacey in a major critique subtitled 'the need to rethink management after the collapse of investment capitalism' states the problem starkly:

Recent economic events of credit crunch and recession must surely be making it very difficult for all but the most wilfully blind to avoid questioning whether senior executives in organizations really can do what the dominant management prescriptions call for. ... it is assumed, without much questioning, that small groups of powerful executives are able to choose the 'direction' their organization will move in, realize a 'vision' of it, create the conditions in which its members will be innovative and entrepreneurial, and select the 'structures' and 'conditions' which will enable them to be in control and so ensure success ... However, recent and current economic developments are making it more than usually clear that executives of large corporations and their management consultants, as well as politicians and their advisors, are far from sure of what has been happening and they simply do not know what is now happening, let alone what will happen in the future as a consequence of the actions they are taking. (Stacey, 2010, p. 1)

Stacey does not simply point out that the emperor has no clothes: he analyses in detail why nudity has come to dominate the leadership fashion scene; why it is hard to displace; the role which systems thinking plays; and what a more attentive way of thinking about organisational reality might be.

Stacey's pessimism seems justified: at the same time comes (according to Warren Bennis' contribution to the frontispiece)

... the book that the world has been anxiously waiting for, perhaps Kanter's most notable, certainly one of the most important books of this decade. This is a must-

\footnotetext{
${ }^{7}$ As Greenspan argues she did, averting through a shift in the euro/dollar exchange rate a widelyexpected crisis in the first half of the last decade (Greenspan, 2009, p. 38).

Page | 12
} 
read for all our current and future leaders who will profit enormously from her lessons on how organizations can succeed in these perilous times. (Kanter, 2009)

'Profit' may prove correct, although not quite in the way Bennis intended; for what Kanter contributes to is the reinvention of a collective dream in which (crash or no crash) leaders remain extraordinary individuals deserving to be remarkably well paid. In this case, from three years of qualitative research involving 350 interviews mainly with corporate executives in 20 countries, Kanter has discerned evidence which will persuade even sceptics (ibid., p. 8) that out of the ashes is arising a new type of global company - vanguard companies - which herald a new dawn:

The vanguard model turns organizations upside down and inside out. They become less hierarchical and more driven by flexible networks. They become more open and transparent to the outside world while bringing society and its needs inside. As an ideal and as an aspiration, the vanguard model attempts to reconcile contradictions: to be big but human, efficient but innovative, respecting individual differences while seeking common ground, global in thinking but concerned about local communities. (Ibid., pp. 265-266)

\section{Moreover:}

The vanguard model not only demands more leaders: it demands more of them. (Ibid., p. 262)

And even though these companies have been turned 'upside down', with highly empowered front line staff, it is the leaders who matter:

Ultimately, a vanguard company is only as good as leaders' ability to attract, motivate and retain skilled people and enable them to self-organize and collaborate. [35: 28](emphases added)

According to Kanter, what will the fashionable leader be wearing in the coming, postcrash decade? In full:

Intellect: Systems thinking. Can see things in context, can understand complex interactions among many variables. Has tolerance for ambiguity. Is skilled in pattern recognition, seeing similarities and differences, framing and conceptualizing. Has intellectual curiosity; the desire to learn and understand. Has a cosmopolitan outlook and is able to put local actions or places in a broader perspective.

Action: Initiative taker. Has a bias for action and a desire for solutions. Seeks problems to solve. Sets big goals, then breaks them down into practical tactics. Abhors passivity; wants to get moving, to find steps to take in any circumstance. Can envision a sequence of actions and their consequences. Understands what 
drives or impedes change, can strategize around barriers. Is energetic and has physical stamina. Is results oriented.

Relationships: Persuasion and diplomacy. Can communicate, listen, and inspire. Likes to connect, to collaborate, and to find solutions that are good for many people. Can enlist people in projects and motivate volunteers. Is partnership oriented, seeing opportunities to leverage resources by tapping networks. Work as an effective, enthusiastic mentor.

Emotion: self-awareness and empathy. Has strong self-knowledge, awareness of limitations as well as strengths. Can put self in others' shoes and analyze their perspective, respect their individuality. Can hold own ego in check while making gestures that address others' emotional reactions. Is willing to invest in activities that build emotional bonds.

Spirituality: Values driven. Is a good steward of resources for all stakeholders, including investors, while remaining attuned to long-term sustainability. Is attuned to a higher purpose beyond only making money. Cares about values and ethics, about the impact of business on society. Believes in the transformative power of service. (Ibid., pp. 261-262)

To put it another way, nudity will still be in fashion. Most recruiters will not need to make many changes to the person specifications already stored on their computers. We can recall, from Arendt's point of view, how a totalitarian vision ${ }^{8}$ must be based on more than greed. More importantly, it will quite probably be a 'vanguard company' - or one pursuing its own version of this agile, innovative, pace-setting approach - which will create the first ninja mortgages or 'CDOs-squared' of the crisis of 2018. Kanter's position - that her vision is of companies which care deeply about society and so are unlikely to do any such things - confronts head-on Stacey's attack, that, caring or not, we are unable to control or predict what we unleash. The noise outside the window is of complex juggernauts hurtling into fog and ice.

\section{A deafening silence}

From noise to a silence. The global crisis has produced a torrent of lesson-learning: unsurprising, since this crisis defines our times and still threatens our futures. What is surprising is this. We are drowning in proposals for reform (many of them important and necessary) which start as far outside the skin of individual firms as managing the world's economic imbalances better, or banning utility banks from undertaking casino activities. Proposals still come thick and fast as we draw closer to the individual firm,

\footnotetext{
${ }^{8}$ Bob McDonald, vice-chairman of one of Kanter's vanguard companies, Procter \& Gamble, has this concept of democracy: 'P\&G is a democracy of ideas, and 99.9 per cent of the time if all managers have the same data, they all make the same decisions due to the strength of our values.' While Kanter's thesis stresses innovation and diversity, this is to be grown in the soil of strongly common and superficially apolitical corporate values (ibid., p. 94).
} 
through proposals for new taxation, more intrusive regulation and finally strengthened internal governance: the role of the firm's board and non-executives. But excepting remuneration, there is a deafening silence about questions striking at the heart of firms, such as how executive leadership is carried out.

The crux of the matter, this paper suggests - certainly it was for someone like Arendt - is the social, moral and creative nature of humanity. If we fail to grasp our own nature or fail to translate this into our organisational practices, we risk not only moral damage but also trying to prevent future crises with tools which will not work, because they were not designed for us.

The reductionism of key concepts in human resources such as competencies (Boyatzis, 1982) to stimulus-response behavioural models is important (hence the references in this paper to rats). Competencies have enabled massive projects of human engineering in complex, often international, organisations - enabling firms to track, place and develop their 'human assets' and also to promote through appraisal, training and reward systems desired behaviours. But the impoverished understanding of ourselves which underlies much of this successful 'human engineering' (Bolton and Houlihan, 2007) produces the thinness of the present discussion about how we might act and lead differently - in particular the virtual collapse of this debate to pieces of cheese and where we might put them.

Post-crisis economics, however, is rather excited about the possibility of progressing towards humans as rats! That is because the starting point of much modern economics has been humans as robots or computers. Behavioural economics is the rage: the financial crisis has become a stake to be driven into the heart of the rational expectations beast. For example:

Orthodox economics has been humiliated. Families bought houses they could not pay for, often with drastic consequences. Consumers, egged on by cheap credit, made purchases they would later regret. Sophisticated financial minds hopelessly miscalculated the value of assets. Top investment banks took ruinous commercial decisions. These mistakes were replicated and repeated. Orthodox economics, meanwhile, says economic agents take independent, rational decisions that maximise their own self-interest. Oops. (Lunn, 2009, p. 15)

The pattern in behavioural economics is to explore how human thinking in practice is biased, takes short cuts or blind alleys, or is distorted by group interaction. A notable example of the progress in economics from robots to rats is Coates' and Herbert's study of testosterone and cortisol in stock market traders (Coates and Herbert, 2008). One of the most popular book-length examples is 'Nudge' (Thaler and Sunstein, 2008). Another major 'new' economics study emphasised the biological theme with its title 'Animal Spirits' (Akerlof and Shiller, 2009).

If contemporary human resource thinking is unduly about rats, while post-crisis economics is excited about progressing from robots towards rats, how marvellous it 
would be if both fields could raise their aspirations towards the fully human. This paper has suggested that this would include continuing to unmask the false scientification and ethical improverishment about which Ghoshal, Khurana, Griffin, Stacey and Froud et al have written, and working towards less brittle and more moral leadership practices. Of course, others would see a fuller humanisation quite differently. Regardless of these differences, in the aftermath of the trillion dollar crash all of us practising and thinking about leadership have the opportunity - and the urgent need - to turn the examination of leadership's contribution to this global débâcle from ghost into substance.

\section{Acknowledgements}

Michael Foot, Douglas Griffin, Deirdre Hutton, Michael Mainelli, James McCalman, David Newkirk, Charles Roxburgh and David Sims generously commented on an earlier draft of this paper; naturally the views expressed remain the author's responsibility. Gresham College, London kindly provided the opportunity to explore some of these arguments in a lecture on 26 January 2010 'Confessions of a regulatory headhunter: how we led ourselves into financial crisis'.

\section{References}

Akerlof, G. and Shiller, R. (2009). Animal Spirits: How Human Psychology Drives the Economy and Why It Matters for Global Capitalism. Princeton University Press, Princeton.

Arendt, H. (2003a). Expansion. In P. Baehr (ed.), The Portable Hannah Arendt (pp. 104-118). Penguin, London.

Arendt, H. (2003b). Total Domination. In P. Baehr (ed.), The Portable Hannah Arendt (pp. 119-145). Penguin, London.

Argyris, C. (1990). Overcoming Organizational Defenses: Facilitating organizational learning. Simon \& Schuster, Boston.

Barber, M. (2008). Instruction to Deliver: Fighting to Transform Britain's Public Services. Methuen Publishing, London.

Bolton, S. and Houlihan, M. (eds.). (2007). Searching for the Human in Human Resource Management: Theory, Practice and Workplace Contexts. Palgrave Macmillan, Basingstoke.

Boyatzis, R. (1982). The Competent Manager: A Model for Effective Performance. John Wiley \& Sons, New York.

Burns, J. (1978). Leadership. Harper \& Row, New York.

Canovan, M. (1992). Hannah Arendt: A Reinterpretation of Her Political Thought. University of Cambridge Press, Cambridge. 
Coates, J., \& Herbert, J. (2008). Endogenous steroids and financial risk taking on a London trading floor. Proceedings of the National Academy of Sciences, 105 (16), 6167-6172.

Collins, J. (2001). Good to Great. Harper-Collins, New York.

Financial Services Authority. (2009). The Turner Review: A regulatory response to the global banking crisis. FSA, London.

Financial Times. (2009). The consequences of bad economics. In The Future of Capitalism (p. 39). Financial Times, London.

Froud, J., Johal, S., Leaver, A. and Williams, K. (2006). Financialization and Strategy: Narrative and numbers. Routledge, London.

Ghoshal, S. (2005). Bad Management Theories Are Destroying Good Management Practices. Academy of Management Learning \& Education, 4, 75-91.

Gieve, J. (2009). Seven lessons from the last three years. Bank of England, London.

Greenspan, A. (2009). We need a better cushion against risk. In The Future of Capitalism (pp. 36-38). Financial Times, London.

Griffin, D. (2002). The Emergence of Leadership: Linking self-organization and ethics. Routledge, London.

H M Treasury. (2009). Pre-Budget Report 2009: Securing the recovery: growth and opportunity (Cm 7747). H M Treasury, London.

International Monetary Fund. (2009). Global Financial Stability Report: Navigating the Financial Challenges Ahead (October 2009). IMF, Washington DC.

Jackson, M. C. (2003). Systems Thinking: Creative Holism for Managers. John Wiley and Sons, Chichester.

Kanter, R. (2009). Supercorp. Profile Books, London.

Kellaway, M. (2009). Public Sector Interventions in the Financial Crisis: Statistical Classification Decisions. Office for National Statistics, Newport.

Khurana, R. (2002). Searching for a Corporate Savior: The Irrational Quest for Charismatic CEOs. Princeton University Press, Princeton.

Khurana, R. (2007). From Higher Aims to Hired Hands: The Social Transformation of American Business Schools and the Unfulfilled Promise of Management as a Profession. Princeton University Press, Princeton.

Kotter, J. (1988). The Leadership Factor. The Free Press, New York.

Lunn, P. (2009). The descent of rational man. Royal Society for the Arts Journal, spring 2009, 14-21. 
Mainelli, M. and Giffords, B. (2009). The Road to Long Finance: A Systems View of the Credit Scrunch. Centre for the Study of Financial Innovation, London.

Mintzberg, H. (2009) The view from here. Director magazine, November 2009. Online: <http://www.director.co.uk/magazine/2009/10\%20November/view_fr om_here_63_03.html > (accessed 16 May 2010).

Nonaka, I. and Takeuchi, H. (1995). The Knowledge-Creating Company: How Japanese Companies Create the Dynamics of Innovation. Oxford University Press, Oxford.

Papademos, L. (2009). The role of the ECB in financial crisis management: speech of 27 May 2009. European Central Bank, Frankfurt.

Senge, P. (1990). The Fifth Discipline: The Art and Practice of the Learning Organization. Doubleday, New York.

Soros, G. (2008). The New Paradigm for Financial Markets: The Credit Crisis of 2008 and What It Means. Public Affairs, New York.

Stacey, R. (2010). Complexity and Organizational Reality: Uncertainty and the Need to Rethink Management after the Collapse of Investment Capitalism. Routledge, Abingdon.

Thaler, R. and Sunstein, C. (2008). Nudge: Improving decisions about health, wealth and happiness. Penguin, London.

Turner, A. (2009). The financial crisis and the future of financial regulation. The Economist City Lecture, London.

United Kingdom Parliament. (2009a). House of Commons Treasury Committee Minutes of Evidence 10 February 2009. London.

United Kingdom Parliament. (2009b). House of Commons Treasury Committee Minutes of Evidence 25 February 2009. London.

Vaill, P. (1989). Managing as a Performing Art: New Ideas for a World of Chaotic Change. Jossey-Bass, San Francisco.

Walker, D. (2009a). A review of corporate governance in UK banks and other financial industry entities: 16 July 2009. H M Treasury, London.

Walker, D. (2009b). A review of corporate governance in UK banks and other financial industry entities: Final recommendations 26 November 2009. H M Treasury, London.

Wheatley, M. (1999). Leadership and the New Science: Discovering Order in a Chaotic World. Berrett-Koehler, San Francisco.

Wolf, M. (2009). Seeds of its own destruction. In The Future of Capitalism (pp. 6-9). Financial Times, London. 